\title{
The taxonomy and biogeography of the guttulinervis group of the genus Baeturia Stål, 1866 (Homoptera, Tibicinidae)
}

\author{
A.J. de Boer \\ Institute of Systematics and Population Biology (Zoölogisch Museum), University of Amsterdam, \\ P.O. Box 94766, 1090 GT Amsterdam, The Netherlands
}

Keywords: Baeturia, guttulinervis group, taxonomy, biogeography, New Guinea

\begin{abstract}
The guttulinervis group is proposed for a monophyletic group of four northern New Guinean species of the cicada genus Baeturia Stål, 1866. B. guttulinervis Blöte, 1960, is redescribed and three species ( $B$. biroi, $B$. inconstans, and $B$. roonensis) are described as new to science. The phylogenetic position of the guttulinervis group, within the genus Baeturia, is discussed. The distribution of shared characters suggests a sister group relationship with the conviva group. A key to the males is provided and a map of distribution is presented.
\end{abstract}

\section{Résumé}

On établit le groupe d'espèces guttulinervis pour un groupe monophylétique de quatre espèces de Nouvelle Guinée septentrionale appartenant au genre de cigales Baeturia Stål, 1866. B. guttulinervis est redécrite, et trois espèces $(B$. biroi, $B$. inconstans et $\boldsymbol{B}$. roonensis) sont décrites comme nouvelles pour la science. On discute la position phylogénétique du groupe guttulinervis dans le cadre du genre Baeturia. La distribution des caractères partagés suggère que c'est le groupe conviva qui en est le groupe-frère. On présente une clé pour l'identification des mâles, ainsi qu'une carte de distribution des espèces.

\section{Introduction}

The guttulinervis group of the genus Baeturia Stål, 1866 is a presumed monophyletic group of four species, recognizable by an apical swelling of the claspers. The shape of the male pygofer and caudodorsal beak suggest a sister group relationship with the conviva group.

The guttulinervis group is distributed along the northern mountain ranges of New Guinea, including Roon island and the northeastern part of Cendrawasih, an area particularly rich in Baeturia species.

The genus Baeturia belongs to a supposedly monophyletic group of New Guinean and Australian genera defined earlier as the "Baeturia and related genera complex" (De Boer, 1990). This genus-complex forms a promising group for areacladistic studies on New Guinea and adjacent areas. Preliminary results indicate that the distributions of most of these genera can be associated with fragments of an historical oceanic island arc, which collided 25-2 my ago with the northern leading edge of the Australian continent (see for geological reviews: Hamilton, 1979; Pigram \& Panggabean, 1984; Pigram \& Davies, 1987; Daly et al., 1991). Many fragments of this island arc can still be recognized as areas of endemism for monophyletic groups of cicadas (Duffels, 1986; Duffels \& De Boer, 1990), and differences in biogeographical patterns between the various genera must possibly be explained by their supposed origin on different island arc fragments.

The present publication forms part of a biogeographic and phylogenetic revision of the widely distributed genus Baeturia. Seven monophyletic species groups can be recognized within Baeturia: the bloetei group (De Boer, 1989), the conviva group (De Boer, 1986), the exhausta group (De Boer, in press b), the loriae group (De Boer, in press a), the nasuta group (De Boer, 1982), the viridis group (De Boer, 1992a), and the guttulinervis group described 
here. Several other species, originally described as Baeturia, have been transferred to other genera (e.g. Aedeastria De Boer, 1990 (De Boer, 1993a) and Guineapsaltria De Boer, 1993b), or await to be transferred.

\section{Material and methods}

The material examined for this study comes from the following collections:
AMS Australian Museum, Sydney
BPBM Bernice P. Bishop Museum, Honolulu
CAS California Academy of Sciences, San Francisco KBIN Koninklijk Belgisch Instituut voor Natuurweten-
schappen, Brussel
Moul Personal collection of Mr. M.S. Moulds, Sydney
RMNH Nationaal Natuurhistorisch Museum (formerly: Rijks- museum van Natuurlijke Historie), Leiden
TMB Természettudományi Múzeum, Budapest
ZIM Zoologisches Institut und Zoologisches Museum, Hamburg
ZMA Zoölogisch Museum, Amsterdam
ZMB Institut für Spezielle Zoologie und Zoologisches Mu- seum der Humboldt-Universität, Berlin

The following geographical sources have been used: "Atlas van tropisch Nederland" (anonymous, 1938), "The Times Atlas of the World" (anonymous, 1968) and a "List of New Guinea localities" published by the Bernice P. Bishop Museum (anonymous, 1966).

After overnight softening, male genitalia were examined by pulling out the pygofer with a sharp needle inserted between pygofer and 8th abdominal segment. The aedeagus was pulled out at the same time, by inserting the needle between the claspers. For all specimens body length and tegmen length were measured; other measurements are based on a maximum of ten specimens.

\section{Phylogeny}

\section{The monophyly of the guttulinervis group}

The species of the guttulinervis group share a straight and posteriorly directed club-shaped clasper, which is apically distinctly swollen. This apical swelling of the clasper, though variable in shape between the four species, is regarded apomorphous for the guttulinervis group.
The phylogenetic position of the guttulinervis group

Seven monophyletic species groups are recognized within the genus Baeturia, but the phylogenetic position of one of these groups, the loriae group, is very uncertain, since species of that group combine Baeturia characters with characters typical of the genus Gymnotympana. Current phylogenetic analysis shows, however, that inclusion of the loriae group into the genus Baeturia is the most parsimonious solution (De Boer, in press a). Some probable relationships between the remaining species groups of Baeturia have already been discussed (De Boer, 1992a). The conviva group (De Boer, 1986), the guttulinervis group, the nasuta group (De Boer, 1982), and the viridis group (De Boer, 1992a) presumably form a monophyletic group, sharing a distinctly posteriorly projecting protuberance on the lateral lobe of the pygofer, which is regarded as synapomorphous.

Furthermore these four groups share a very stout and strongly bent caudodorsal beak. Other species of Baeturia have much smaller, bluntly rounded, and more laterally situated protuberances, and they generally have a more erect and often more slender caudodorsal beak (cf. the bloetei group, De Boer, 1989; the exhausta group, De Boer, in press b; the loriae group, De Boer, in press a); a strongly bent caudodorsal beak or posteriorly projecting protuberances only sporadically occur in genera related to Baeturia.

The conviva group and the guttulinervis group are presumably sister groups. They share, as a possible synapomorphy, a dorsally strongly rounded pygofer, in which the dorsal margin is continuously, or almost continuously, rounded with the dorsal margin of the caudodorsal beak, and in which the beak is rounded, almost pointed, at its apex. A similarly dorsally rounded pygofer is found in some Melanesian species of the bloetei group (De Boer, 1989), which probably must be explained as a homoplasy. The caudodorsal beak is angularly bent, with straight dorsal margin, and generally truncate at its apex in the nasuta group and the viridis group. Furthermore, two species of the guttulinervis group share a distinct crest between the 
lateral lobes of the aedeagus with many species of the conviva group (unpublished). A similar crest is only found in the species of the loriae group, the group with the uncertain phylogenetic position.

\section{In-group relationships}

It is at present not possible to construct an unambiguous phylogeny for the guttulinervis group. Though several characters were found, which are shared by some, but not all of the species, these characters generally also occur in other species groups of Baeturia, thus limiting their phylogenetic value.

Nevertheless, there are some indications that $\boldsymbol{B}$. biroi $\mathbf{n}$. sp. and $B$. inconstans $\mathrm{n}$. sp. are sister species. These two species are of about the same size, distinctly smaller than both other species; they share relatively smaller tymbals with only four or five sclerotized ridges spanning the tymbal from dorsal to ventral margin, and very similar claspers, with a distinct crest along the clasper hollow (compare Figs. $25 \& 35$ arrows). The somewhat reduced tymbal size and the crest around the clasper hollow might both be synapomorphies for these two species. The number of tymbal ridges varies within Baeturia; four ridges is regarded apomorphous for the nasuta group (De Boer, 1982), but five ridges is rare, only found in one other species, $B$. guttulipennis Blöte, 1960, which is closely related to the nasuta group. However, the phylogenetic position of $\boldsymbol{B}$. inconstans is somewhat uncertain, since the species shares a strongly concave distal margin of the pygofer and a sharply edged protrusion on the lateral lobe of the pygofer with species of the viridis group (De Boer, 1992a).

$B$. biroi and $B$. guttulinervis Blöte, 1960, share a short and rounded protrusion on the lateral lobe of the pygofer, a fairly long clasper with similarly rounded clasper heel, and a distinct crest between the aedeagal lobes. $B$. roonensis $\mathrm{n}$. $\mathrm{sp}$. and $B$. inconstans have a longer and more pointed protrusion on the lateral lobe of the pygofer, shorter claspers, and no crest between the aedeagal lobes. The length of the protrusion on the pygofer lobe varies strongly in the related species groups, while a crest between the aedeagal lobes is also found in some species of the conviva group (unpublished) and is shared by all species of the loriae group (De Boer, in press a). The phylogenetic significance of the differences in clasper length is not clear.

The tegmina of $B$. guttulinervis and B. roonensis have a much narrower costal area than those of $B$. biro $i$ and $B$. inconstans, but such differences also occur in other species groups of Baeturia.

\section{Biogeography}

The guttulinervis group is endemic to northern New Guinea, occurring from the eastern coast of Cendrawasih (= Vogelkop peninsula) in the west, to the Huon peninsula and the northwestern corner of the Papuan peninsula in the east. $B$. inconstans spans the whole length of this range, but the other species have a more limited distribution: $B$. roonensis is probably endemic to Roon Island, B. guttulinervis is restricted to a small area in central Irian Jaya just north of the central mountain ranges, and $B$. biro i is distributed to the east, from Sentani to the Huon peninsula (Fig. 1).

New Guinea is of composite geological origin. The island was formed after a series of collisions of the northern leading edge of the Australian tectonic plate, with various microcontinents (especially in western New Guinea) and parts of an oceanic island arc, known as the Outer Melanesian Arc (Hamilton, 1979; Pigram \& Davies, 1987; Rangin et al., 1990a, 1990b; Daly et al., 1991). The area in which the guttulinervis group occurs almost completely originates from this island arc, and comprises those terranes, which accreted most recently (10-2 My ago) to New Guinea (e.g. the Arfak, Gauttier, Torricelli, and Finisterre terranes, see Pigram \& Davies, 1987). These are roughly the terranes north of the Mamberamo, Sepik, and Ramu-Markham Rivers.

The cicada genus Baeturia has a particularly wide distribution, from Timor to Samoa and Tonga (De Boer, 1989), but the genus has a striking amount of endemic species in these northern parts of New Guinea. For example, the viridis group has a monophyletic subgroup of four species (B. furcillata, 


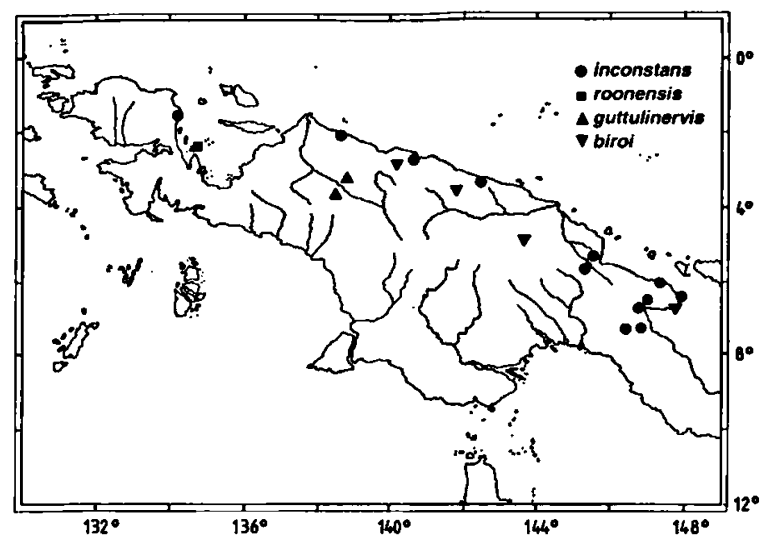

Fig. 1. Distribution of the species of the Baeturia guttulinervis group.

B. karkarensis, B. rufula, and B. turgida) with a remarkably similar distribution pattern as the guttulinervis group (De Boer, 1992a). But also the exhausta group has several species in that particular area (De Boer, in press b). In contrast, several other New Guinean cicada genera seem concentrated in other parts of the island. Diceropyga Stål, 1870, Gymnotympana Stål, 1863, and Thaumastopsaltria Kirkaldy, 1900, appear concentrated with most of their species in the Papuan peninsula, while $A e$ deastria De Boer, 1990, and Rhadynopyga Duffels, 1985, are centred in western New Guinea and adjacent islands (De Boer, 1992b; 1993a); these are both areas where the genus Baeturia has remarkably few endemics. It is supposed that these differences in distribution patterns of the various genera indicate their different origin on the various parts of the Outer Melanesian Arc. The ancestor of Baeturia might originate from either the Torricelli or the Finisterre terrane, two remnants of the arc that ended up in northern New Guinea; while for example Diceropyga, Gymnotympana, and Thaumastopsaltria all probably originate from parts of the island arc that now form the Papuan peninsula.

The sister group of the guttulinervis group, the conviva group, is distributed in Cendrawasih and on the islands of Aru, Bacan, Buru, Halmahera, Obi, Seram, Sula, and Roon (De Boer, 1986; unpublished data), possibly indicating a paleogeological relationship between northern New Guinea and at least part of the northern Moluccas. It is remark- able that both the guttulinervis group and its sister group appear to have an endemic species on the tiny Roon Island.

\section{Taxonomy \\ Description of the guttulinervis group}

Body ochraceous brown, often with brown speckling on head, thorax, and predominantly the dorsal parts of the abdomen, sometimes with lighter coloured and unspeckled middorsal band from postclypeus to apex of caudodorsal beak. Females often shorter than males, but with more robust head and thorax, longer tegmina, and generally more densely speckled. Male abdomen 1.3-1.5 times as long as head and thorax, of females 1.0-1.3 times as long. Tegmina of males 1.1-1.3 times as long as body length, of females 1.3-1.5 times as long.

Head: Ochraceous, generally brown speckled on postclypeus and vertex lobes, sometimes unspeckled between ocelli. Postclypeus 1.4-2.3 times as broad as long, and distinctly protruding beyond vertex lobes, broadly rounded anteriorly and set with long setae. Distance between eyes 1.5-2.0 times as long as postclypeus width. Head only slightly narrower than anterior width of pronotum; pronotal collar 1.2-1.5 times as wide as head. Head 2.2-2.6 times as wide as distance between eyes. Vertex fairly narrow, $1.5-2.0$ times as wide as long. Ocelli large and fairly close together; distance between lateral ocelli $0.7-1.4$ times as long as distance between eye and lateral ocellus and 1.0-1.9 times width of frontal ocellus. Eyes 0.6-0.8 times as wide as distance between eyes.

Thorax: Pronotum 2.0-2.3 times as broad as long, with two pairs of deep oblique fissures. Speckling often most dense between fissures and in medial band, but sometimes completely absent in medial band. Mesonotum often lighter coloured greyish brown, sometimes with two vaguely darkened semicircular spots at pronotal collar, and darkened lateral bands, converging from pronotal collar to cruciform elevation; sometimes two black spots in front of elevation. Mesonotum 0.7-0.8 times as long as width of pronotal collar. 


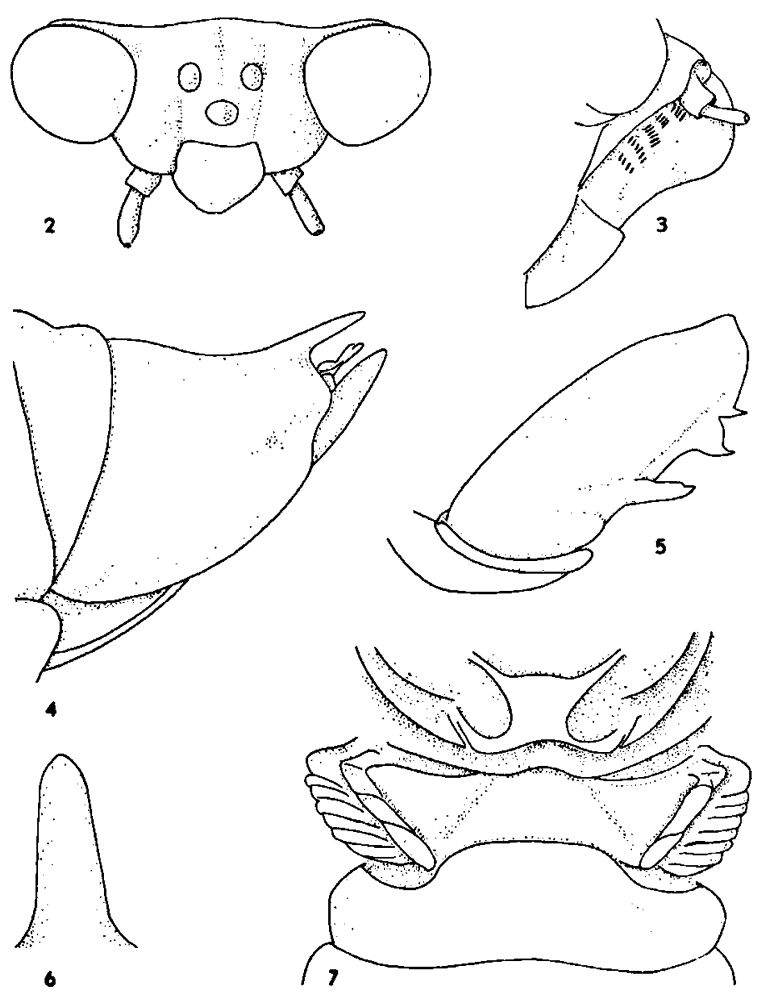

Figs. 2-7. Baeturia guttulinervis Blöte, 1960: 2, head in dorsal view, holotype; 3 , head in lateral view, holotype; 4 , female pygofer in lateral view, allotype; 5 , fore femur, holotype; 6 , female caudodorsal beak in dorsal view, allotype; 7 , male 1st and 2nd tergite in dorsal view, holotype.

Tegmina and wings: Hyaline. Tegmina generally with 8 , but in $B$. inconstans with $10-14$, apical areas. Last apical area fairly short, squarish, though longer and more slender in $B$. roonensis. Wings with 6 apical areas. Venation ochraceous or greenish, and fairly densely set with setae. Tegmen with narrow hyaline border along hind margin, this border slightly broader in wing.

Legs: Fore femur (Fig. 5) with row of three or four pointed and erect spines, diminishing in length towards tibia. Middle spine triangle-shaped, very broad at its base. Proximal spine slightly longer than middle spine and about as long as distance to middle spine.

Opercula: Consisting of a vaulted basal part, with a distinct crest around its distolateral corner. The distal part of this crest amplifies to a flat distal part of the operculum. This distal part is oval- shaped in males and reaches medially of the meracanthus; that part is much smaller, sickle-shaped, in females.

Tymbal: With 5-12 parallel sclerotized ridges spanning the tymbal.

Abdomen: Male abdomen very delicate, distinctly inflated; segmental hind margins generally reddish. Ventrolateral row of dark spots on segments 3-7 or 8. First tergite (Fig. 7) fairly short and generally partly hidden under metanotum. Anterior margin of 2nd tergite straight or weakly concave medially. Lateral parts of 2nd tergite weakly inflated and adjacent to tymbal. Anterior margin of ventral part of 2nd tergite straight between auditory capsule and 1st sternite. Auditory capsules distinctly swollen. First sternite broad and bluntly rounded distally, adjacent to 2nd sternite. Distal margin of 8 th tergite weakly concave. Female abdomen more solid than that of male, and more densely speckled; colouration of segmental hind margins and ventrolateral spots less distinct. Female pygofer (Fig. 4) with fairly long, upcurved and apically pointed caudodorsal beak. Ovipositor sheaths reaching to, or just beyond, apex of beak.

Male genitalia: Pygofer rounded, with very stout and strongly bent caudodorsal beak. Dorsal margin of pygofer strongly convex, continuous with rounding of caudodorsal beak, sometimes distinctly concave near apex of beak. Ventral margin of pygofer angularly convex; ventral margins converge to form a sharp angle at base of pygofer. Caudodorsal beak reversed gutter-shaped and rounded, almost pointed, at apex (cf. Fig. 26). Lateral lobes of pygofer bear distinctly posteriorly projecting conically shaped protuberances. Claspers parallel and straight, not fused at base, and thus not forming a collar around base of anal valves. Distinct crest along dorsal margin of clasper. Clasper either gradually broadening towards base, or abruptly broadening dorsally, and forming a rectangular corner, here termed "clasper heel" (Fig. 9). Apical part of clasper somewhat club-shaped, ending in a globularly swollen dorsodistal protuberance. The sharply edged ventral incurvation or "clasper hollow" is very short, its distal margin lies proximally of the clasper apex. Aedeagus S-curved, with two small lateral lobes at base of curvature, in $B$. biroi 
and $B$. guttulinervis connected by a ventral ridge. Aedeagus in lateral view weakly concave along its pore. Aedeagal pore narrow and oval.

\section{Key to the males}

1a Body length under $18 \mathrm{~mm}$. Tymbal with 5-6 sclerotized ridges. Aedeagus slightly concave between its lateral lobes (Figs. 28, 39) ....................... 2

b Body length over $20 \mathrm{~mm}$. Tymbal with 7 or more sclerotized ridges. Aedeagus strongly concave between its lateral lobes (Figs. 13, 23) $\ldots \ldots \ldots \ldots \ldots \ldots \ldots \ldots \ldots \ldots \ldots \ldots$

2a Tegmina with eight apical areas. Tymbal with 6 sclerotized ridges. Clasper long, missing a distinct clasper heel (Fig. 25). Protuberances on lateral lobes of pygofer short and conically shaped, bluntly rounded at apex. Distal margin of pygofer slightly concave, not continuous to apex of protuberance (Fig. 24). Aedeagus with distinct crest between its lateral lobes (cf. Fig. 11 arrow). Lateral lobes of aedeagus long and slender (Fig. 29) ................ B. biroi $n$. sp.

b Tegmina with variable number (10-14) of apical areas. Tymbal with 5 sclerotized ridges. Clasper short, with distinct rectangular clasper heel (Fig. 35). Protuberances on lateral lobes of pygofer long, with sharp lateral edge, and almost pointed at apex. Distal margin of pygofer strongly concave, continuous to apex of protuberance (Fig. 33). Aedeagus without crest between its lateral lobes (cf. Fig. 22). Lateral lobes of aedeagus short and broad (Fig. 38) .......... $\ldots \ldots \ldots \ldots \ldots \ldots \ldots \ldots \ldots$. inconstans n. sp.

3a Tegmina with dark spots along veins. Tymbal with 7 ridges. Operculum reaching beyond apex of meracanthus. Protuberances on lateral lobes of pygofer short and bluntly rounded at apex. Aedeagus with distinct crest between its lateral lobes (Fig. 11) ...... B. guttulinervis Blöte, 1960

b Tegmina immaculate. Tymbal with 12 ridges. Operculum very short, not reaching apex of meracanthus. Protuberances on lateral lobes of pygofer, conically shaped and pointed at apex. Aedeagus without crest between its lateral lobes (Fig. 22) .................. roonensis n. sp.

\section{Description of the species}

\section{Baeturia guttulinervis Blöte, 1960}

(Figs. 1-15)

Baeturia guttulinervis Blöte, 1960: 67-69, Figs. 13-14; Duffels \& Van der Laan, 1985: 252; De Boer, 1992a: 164-165.

Material examined. - IRIAN JAYA: New Guinea (W.): Araucaria camp, $800 \mathrm{~m}, 8$. iii.1939, L.J. Toxopeus, Neth. Ind.-American New Guinea Exped., 1 \& allotype, RMNH; same data but 10.iii.1939, o holotype, RMNH; Rattan camp,
1200 m, ii.1939, L.J. Toxopeus, Neth. Ind. - American New Guinea Exped., 1 o paratype, 2 \& paratypes, RMNH.

Remarks. $-B$. guttulinervis is easily recognized by its straight clasper and the dark spots along the veins of the tegmina. Females are densely brown speckled.

Description.-Body of males pale ochraceous, holotype with brown speckling on vertex lobes, lateral parts of thorax and dorsal part of abdomen, paratype almost immaculate. Females dark brown suffused, with almost black spots all over body. Males and females with light and immaculate middorsal band, most conspicuous on pronotum and abdomen. Females slightly larger than males, with distinctly longer tegmina. Male abdomen 1.4-1.5 times as long as head and thorax, of females 1.1-1.2 times as long. Tegmina of males 1.1-1.2 times as long as total body length, of females 1.4 times as long.

Head (Fig. 2): Light ochraceous, brown speckled, predominantly on vertex lobes and lateral parts of postclypeus. Females with large black spots on vertex lobes, but generally lighter speckled, or unspeckled, between ocelli. Postclypeus angularly protruding, 1.4-1.6 times as broad as long. Anterior margin of postclypeus broadly rounded. Postclypeus distinctly swollen, anterior margin (lateral view Fig. 3) convex to almost angularly bent.

Thorax: Pronotum light brown with ochraceous medial band, lateral parts slightly brown speckled in holotype, unspeckled in male paratype, and densely dark brown speckled, almost black along immaculate medial band, in females. Pronotal collar in most specimens lighter ochraceous and brown speckled. Mesonotum greyish brown, immaculate in male paratype, but holotype and females with a pair of paramedian dark brown spots at pronotal collar and some irregularly shaped dark spots on lateral parts. Cruciform elevation lighter coloured ochraceous and unspeckled. Pair of black spots in front of cruciform elevation only vaguely visible.

Tegmina and wings: Hyaline, though tegmina slightly bronzed and with irregularly shaped brown spots along venation; these spots most distinct in females. Tegmen with 8, wing with 6 apical areas; 


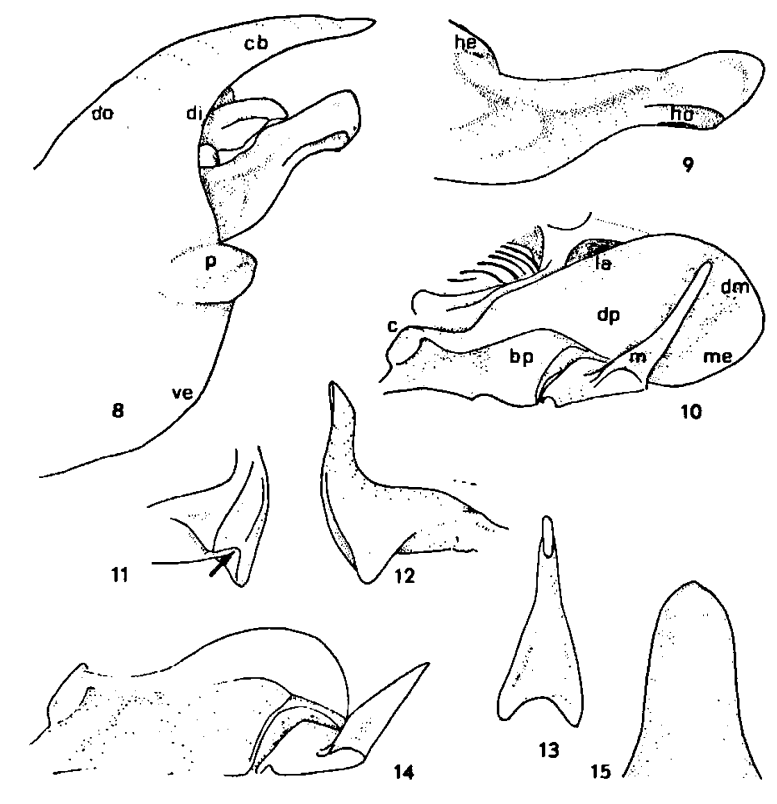

Figs. 8-15. Baeturia guttulinervis Blöte, 1960: 8, male pygofer in lateral view, paratype; 9 , clasper, holotype; 10 , male operculum, paratype; 11 , detail of crest between lateral lobes of aedeagus (arrow), paratype; 12, aedeagus in lateral view, paratype; 13 , aedeagus from behind, paratype; 14, female operculum, allotype; 15 , male caudodorsal beak in dorsal view, paratype. Lettering: $b p=$ basal part of operculum; $c=$ crest around distolateral corner of basal part of operculum; $\mathrm{cb}=$ caudodorsal beak; $\mathrm{dm}=$ distal margin of operculum; di = distal margin of pygofer; do = dorsal margin of pygofer; dp = distal part of operculum; he = clasper heel; ho = clasper hollow; la = lateral margin of operculum; $m=$ meracanthus; $m e=$ medial margin of operculum; $p=$ protuberance on lateral lobe of pygofer; ve $=$ ventral margin of pygofer.

veins fairly densely set with short setae. Costal area of tegmen very narrow.

Tymbal: Seven transverse sclerotized ridges spanning the tymbal from dorsal to ventral margin. Most proximal ridge narrowing considerably towards ventral margin and only just reaching it. Intercalary ridges could not be discerned.

Opercula: Male operculum (Fig. 10) fairly large. Distal part of male operculum oblong-shaped, covering greater part of tymbal cavity in ventral view. Lateral margin long and straight, strongly bending mesiad, forming an obtuse angle with rectangular crest around operculum base. Distomedial corner of operculum broadly rounded and reaching beyond margin of abdomen. Medial margin slightly convex, angularly bending towards base of meracanthus. Apex of meracanthus almost reaching distal margin of operculum. Female operculum (Fig. 14) sickle-shaped and erect. Basal part of female operculum much larger than in male.

Abdomen: Male abdomen light brown, almost immaculate in paratype, but with darkened middorsal band in holotype. Segmental hind margins dark brown, ventrolateral row of black spots very distinct, especially in holotype. Female abdomen more densely covered with dark spots, forming pairs of dorsal, lateral, and ventrolateral bands, but with a light, narrow and immaculate, middorsal band. Dark markings tend to form longitudinal streaks on segment 9. Ovipositor sheaths reaching just beyond apex of caudodorsal beak (Fig. 4). Female caudodorsal beak (Fig. 6) long, slender and pointed at apex.

Male genitalia: Pygofer in lateral view (Fig. 8) stoutly rounded, dorsal margin broadly convex, continuous with fairly slender and slightly erect caudodorsal beak, but slightly concave near apex of beak. Distal margin convex near lateral protuberance, but concavely rounded into margin of beak. Lateral lobes of pygofer with bluntly rounded, distinctly posteriorly projecting protuberances, reaching well beyond pygofer margin. Ventral margin angularly convex; ventral margins converge to a sharp angle at base of pygofer opening (cf. Fig. 26). Caudodorsal beak in dorsal view (Fig. 15) very stout and rounded to slightly pointed at apex. Clasper in lateral view (Fig. 9) very long and straight. Dorsal margin of clasper straight, slightly bending upwards at $2 / 3$ of clasper length into inflated and bluntly rounded apical part. Clasper margin strongly bent at clasper apex, recurving to margin of clasper hollow, with most distal margin of clasper hollow proximal to clasper apex. A broadly rounded crest along proximal $2 / 3$ of dorsal margin bends slightly upwards, into rounded clasper heel. Aedeagus in lateral view (Fig. 12) short and stout, with long and broad lateral lobes at base of S-curve. Aedeagus from behind (Fig. 13) strongly concave between its lateral lobes, and with a distinct, though medially very low, crest between the lobes (Fig. 11). Aedeagal pore narrow and oval. 
Measurements. - Body length $\sigma: 21.5 \& 24.3 \mathrm{~mm}$, $९: 23.5-$ $26.0 \mathrm{~mm}$; tegmen length $\sigma^{\prime}: 25.4 \& 27.6 \mathrm{~mm}, \%: 33.4-35.6 \mathrm{~mm}$; head length $\sigma: 1.7 \& 1.9 \mathrm{~mm}, \%: 2.2-2.3 \mathrm{~mm}$; pronotum length o $2.7 \& 3.0 \mathrm{~mm}$, ᄋ : 3.6-3.9 mm; mesonotum length $\sigma^{\circ}: 5.0 \&$ $5.2 \mathrm{~mm}$; १: $5.9-6.8 \mathrm{~mm}$; head width or $4.6 \& 5.1 \mathrm{~mm}$, ᄋ : 5.4-6.0 mm; width of pronotal collar $\sigma: 6.0 \& 7.5 \mathrm{~mm}, Q$ : $8.1-8.8 \mathrm{~mm}$.

Distribution (Fig. 1). - B. guttulinervis is endemic to a small area in central northern Irian Jaya.

Baeturia roonensis n. $\mathrm{sp.}$

(Figs. 1, 16-23)

Material examined. - Holotype: "Roon ex coll. Fruhstorfer" [print yellow brown label, black cadre]; "Determin W.L. Distant" [print grey lable, black cadre], $\sigma^{\circ}, \mathrm{KBIN}$. Other material: same locality label as holotype, vend H. Fruhstorfer, 15.iv.1898, 1 \&, ZIM.

Remarks. - This species closely resembles $B$. guttulinervis, but has immaculate tegmina and more sharply pointed protuberances on the lateral lobes of the pygofer. $B$. roonensis can be recognized by its large number of tymbal ridges (12), a unique feature within Baeturia. The female is conspicuous by a broad and unspeckled middorsal band.

Description. - Body of male ochraceous brown and unspeckled. Female heavily brown speckled, but with a broad, light ochraceous and unspeckled, middorsal band over whole length of body, from postclypeus to caudodorsal beak. Male abdomen 1.5 times as long as head and thorax, of female 1.1 times as long. Tegmina of male 1.1 times as long as total body length, of female 1.3 times as long.

Head: Light ochraceous and unspeckled in male, but densely brown speckled on vertex lobes, in front of frontal ocellus and on lateral parts of postclypeus, in female. Male postclypeus angularly protruding, 1.6 times as broad as long. Female postclypeus much broader, more oblong-shaped, 2.3 times as broad as long. Postclypeus only slightly swollen, less swollen than in B. guttulinervis, anterior margin (lateral view) only weakly convex.

Thorax: Male pronotum pale brown and unspeckled, female pronotum dark brown speckled, but with broad ochraceous and immaculate medial
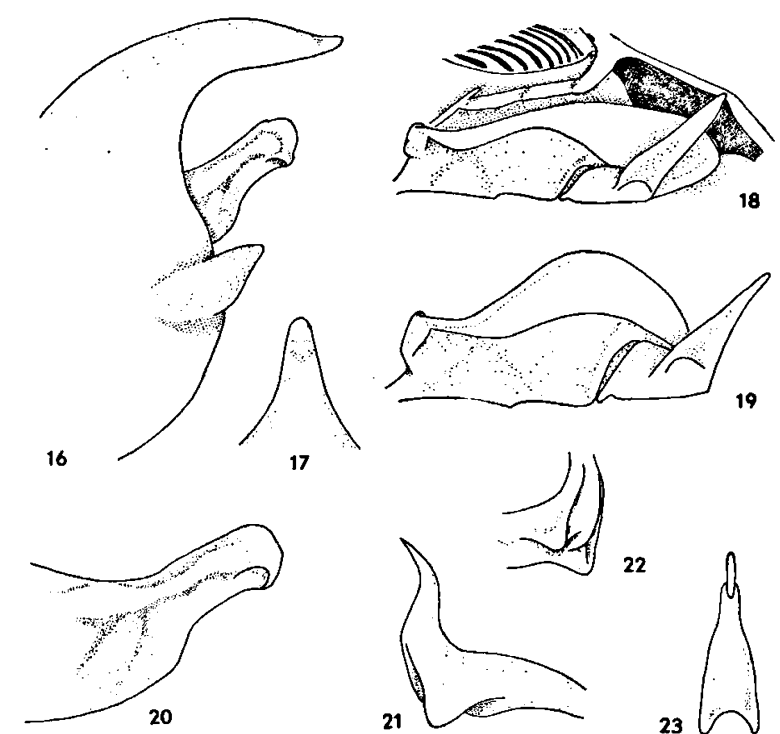

17
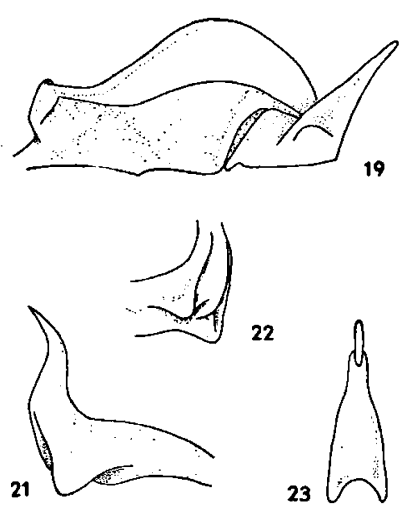

Figs. 16-23. Baeturia roonensis n. sp.: 16, male pygofer in lateral view; 17 , male caudodorsal beak in dorsal view; 18 , male operculum; 19, female operculum; 20 , clasper; 21 , aedeagus in lateral view; 22 , detail of lateral lobes of aedeagus; 23 , aedeagus from behind.

band. Male mesonotum greyish brown, female mesonotum densely brown speckled, but with broad, lighter and immaculate, medial band continuing over cruciform elevation. No black spots in front of elevation.

Tegmina and wings: Hyaline, tegmina with 8, wings with 6 apical areas. Venation very light ochraceous, densely set with short setae in male, almost bald in female. Male with fairly long 8th apical area of tegmen, and missing the basal vein of the 7th apical area in right tegmen. Costal area of tegmen very narrow.

Tymbal: Eleven transverse sclerotized ridges spanning the tymbal from dorsal to ventral margin and a twelfth, most proximal, ridge almost reaching ventral margin. Twelve short intercalary ridges only vaguely visible.

Opercula: Male operculum (Fig. 18) much smaller than that of $B$. guttulinervis, not covering tymbal cavity in ventral view. Distal part of male operculum oval-shaped and erect. Lateral margin almost straight and directed mesiad, forming an obtuse angle with rectangular crest around distolateral corner of basal part. Distomedial corner 
strongly convex, almost rectangular. Operculum extending medially beyond meracanthus. Apex of meracanthus reaching well beyond operculum. Female operculum (Fig. 19) sickle-shaped and erect. Basal part of female operculum much larger than in male.

Abdomen: Male abdomen light brown, almost transparent. Segmental hind margins slightly reddened. A vague row of ventrolateral spots on segments 3-7, almost fused to a continuous line. Female abdomen ochraceous, grey-brown speckled [Female caudodorsal beak damaged].

Male genitalia: Pygofer in lateral view (Fig. 16) strongly rounded as in $B$. guttulinervis but with broader, more strongly bent caudodorsal beak. Dorsal margin of pygofer strongly convex, continuous with caudodorsal beak, distinctly concave near apex of beak. Distal margin convex near lateral protuberance, but concavely rounded into margin of beak. Ventral margin angularly convex; ventral margins converge to a sharp angle at base of pygofer opening. Caudodorsal beak in dorsal view (Fig. 17) very slender, apically rounded. Lateral lobes of pygofer with long, conically shaped, apically pointed protuberances, projecting well beyond pygofer margin. Clasper in lateral view (Fig. 20) closely resembling that of $B$. guttulinervis, but shorter and more directed upwards. Dorsal margin of clasper concave. Clasper apex inflated and bluntly rounded as in B. guttulinervis and, as in that species, with most distal margin of small and stretched clasper hollow proximally of clasper apex; a very distinct, almost wing-shaped crest running along dorsal margin, almost to clasper apex. Clasper heel very low, hardly discernable. Aedeagus in lateral view (Fig. 21) more slender than in $B$. guttulinervis, strongly concave around its pore and almost angularly projecting at half-length of its distal margin. Lateral lobes broad and rounded. Aedeagus from behind (Fig. 23) strongly concave between lateral lobes, but not forming crest between these lobes (Fig. 22). Aedeagal pore narrow and oval.

Measurements. - Body length $\sigma$ : $20.6 \mathrm{~mm}, \propto: 22.5 \mathrm{~mm}$; tegmen length $\sigma^{\circ}: 23.1 \mathrm{~mm}, \wp: 30.3 \mathrm{~mm}$; head length $\sigma: 1.6 \mathrm{~mm}$, ९ : $2.1 \mathrm{~mm}$; pronotum length $\sigma: 2.4 \mathrm{~mm}$, $९: 3.5 \mathrm{~mm}$; mesono- tum length $\sigma: 4.0 \mathrm{~mm}, \wp: 6.5 \mathrm{~mm}$; head width $\sigma^{\circ}: 4.4 \mathrm{~mm}$, $९$ : $5.9 \mathrm{~mm}$; width of pronotal collar $\sigma: 5.8 \mathrm{~mm}, q: 7.7 \mathrm{~mm}$.

Distribution (Fig. 1). - This species is only known from Roon Island in Geelvink Bay.

Baeturia biroi n. sp.

(Figs. 1, 24-32)

Material examined. - Types: Holotype: "N. Guinea / Biró 1898" [print]; "Sattelberg / Huon Golf [print] xii.25" [written on the back], ơ, TMB. Paratypes: same data as holotype but 30.ix.1898, 1 or; 21.xi.1898, 1 ơ; 28.xi.1898, 2 ơ ơ, all TMB; same data, 27.xi.1898, 1 ○’, ZMA.

Other material: IRIAN JAYA: New Guinea (W.): Cyclopen Gebirge, Dr. Mayr I.G., $1 \sigma^{\circ}$, ZMB; Cyclopen Gebirge am Sentanimeer, $1 \sigma^{\circ}$, ZMB; PAPUA: New Guinea (N.E.): Tsenga, upper Jimi Valley, $1200 \mathrm{~m}$, 13.vii.1955, J.L. Gressitt, 1 o , BPBM; same data but 15.vii.1955, 1 \%, BPBM; Wantipi village, Torricelli Mts., 30.xi-8.xii.1958, W.W. Brandt, 1 \%, BPBM.

Remarks. - This species is much smaller than both foregoing species, has only five tymbal ridges and very small male opercula, even smaller than those of $B$. roonensis. It can be recognized by its long and slender aedeagal lobes.

Description.-Body of males ochraceous brown, densely speckled with light brown. The only female, that probably belongs to this species, is much larger than the males and darker brown, with dark brown streaks. Some specimens, including the female, have a light and immaculate middorsal band, most conspicuous on head and pronotum. Male abdomen 1.3-1.5 times as long as body length, of female 1.3 times as long. Tegmina of males 1.1-1.3 times as long as total body length, of female 1.3 times as long.

Head: Light ochraceous, in some specimens brown speckled all over, in others only on vertex lobes and lateral parts of postclypeus. Postclypeus narrow and angularly protruding, 1.4-2.0 times as broad as long. Postclypeus not swollen, anterior margin (lateral view) slightly convex or straight.

Thorax: Pronotum light brown, slightly brown speckled to almost unspeckled; some specimens with lighter and immaculate medial band, others with brown speckling concentrating in medial 

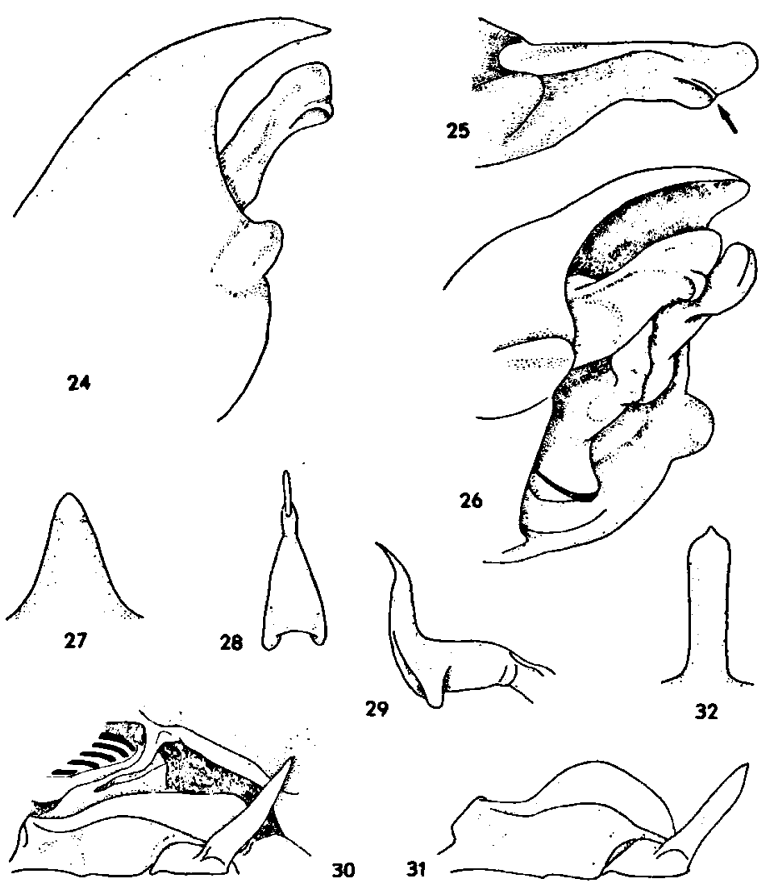

Figs. 24-32. Baeturia biroi n. sp.: 24, male pygofer in lateral view, holotype; 25 , clasper, paratype Sattelberg, arrow indicating crest around clasper hollow; 26, male pygofer from aslant, holotype; 27 , male caudodorsal beak in dorsal view, holotype; 28, aedeagus from behind, Cyclops Mts.; 29, aedeagus in lateral view, Cyclops Mts.; 30, male operculum, holotype; 31, female operculum; 32, female caudodorsal beak in dorsal view.

band. Mesonotum greyish brown, in most specimens brown speckled, but sometimes cruciform elevation and triangular area in front of elevation unspeckled. Pair of distinct dark spots in front of elevation.

Tegmina and wings: Hyaline, tegmina with eight apical areas and a distinct costal area, wings with six apical areas. Venation very light ochraceous and densely set with short setae.

Tymbal: Much smaller than in both foregoing species. Four transverse sclerotized ridges spanning the tymbal from dorsal to ventral margin, a fifth ridge stops close to the ventral margin, and a partly developed, most proximal, ridge, close to the proximal tymbal margin runs to about half the tymbal width. Five short intercalary ridges form a band across the tymbal. Dorsal part of tymbal tinged with red.

Opercula: Male operculum (Fig. 30) very small, slightly smaller than that of $\boldsymbol{B}$. roonensis and only covering a small part of tymbal cavity in ventral view. Distal part of male operculum oval-shaped and almost erect. Lateral margin almost straight and strongly directed mesiad, making an obtuse angle with the rectangular crest around distolateral corner of basal part. Distomedial corner strongly convex, almost angular. Operculum not extending medially beyond meracanthus, but just reaching to medial margin of meracanthus. Apex of meracanthus reaching well beyond operculum. Female operculum (Fig. 31) sickle-shaped and erect. Basal part of female operculum much larger than in male.

Abdomen: Male abdomen light brown, almost transparent, brown speckled in dorsal band and on 8th segment. Segmental hind margins red. Ventrolateral row of dark spots very distinct. Female abdomen dark reddish brown and slightly speckled. Ventrolateral spots vaguely visible. Female caudodorsal beak (Fig. 32) long, slender, and apically pointed.

Male genitalia: Pygofer in lateral view (Fig. 24) strongly rounded as in $B$. roonensis. Dorsal margin convex, continuously rounded with caudodorsal beak, and not concave near apex of beak. Distal margin of pygofer strongly concavely rounded into margin of beak and straight, or sometimes slightly convex near lateral protuberance. Ventral margin angularly convex; ventral margins converge to a sharp angle at base of pygofer opening (Fig. 26). Caudodorsal beak in dorsal view (Fig. 27) short, rounded at apex. Lateral lobes of pygofer with well-developed, bluntly rounded, protuberances, distinctly projecting beyond pygofer margin. Clasper in lateral view (Fig. 25) long and straight as in $B$. guttulinervis. Dorsal margin straight, concavely bending into strongly inflated and rounded apical part. Clasper margin strongly bent at clasper apex, recurving towards a distinct crest around small clasper hollow; most distal margin of clasper hollow lies proximally of clasper apex. A very distinct crest along greater part of dorsal margin broadens to an almost wing-shaped ridge near clasper base. Clasper gradually broadening at base, not forming a clasper heel. Aedeagus in lateral view (Fig. 29) very slender, with slender, narrowly elongate, lateral lobes. Aedeagus from behind (Fig. 28) 
distinctly concave between lateral lobes, forming a very prominent crest between these lobes. Aedeagal pore very narrow and oval.

Measurements. - Body length ơ: 14.6-17.9 mm (mean 16.6 $\mathrm{mm} \pm 1.0$ ), $\&: 20.3 \mathrm{~mm}$; tegmen length $\sigma^{\circ}: 19.0-22.0 \mathrm{~mm}$ (mean $20.8 \mathrm{~mm} \pm 0.8$ ), $\$: 26.5 \mathrm{~mm}$; head length $\sigma:$ : 1.4-1.7 mm (mean $1.5 \mathrm{~mm}$ ), $\%: 1.7 \mathrm{~mm}$; pronotum length $\sigma$ : $: 2.1-2.5$ mm (mean $2.2 \mathrm{~mm}$ ), $\%: 2.8 \mathrm{~mm}$; mesonotum length $\sigma:$ : 3.4-4.1 $\mathrm{mm}$ (mean $3.9 \mathrm{~mm}$ ), $९: 4.8 \mathrm{~mm}$; head width $\sigma^{\circ}: 3.8-4.4 \mathrm{~mm}$ (mean $4.0 \mathrm{~mm}$ ), $\%: 4.6 \mathrm{~mm}$; width of pronotal collar $\sigma^{\prime \prime}$ : 4.7-6.0 mm (mean $5.3 \mathrm{~mm}$ ), \&: $6.5 \mathrm{~mm}$.

Distribution (Fig. 1). - This species is known from northeastern Irian Jaya and northern Papua New Guinea, including the Huon peninsula.

Etymology. - The species was named in honour of Mr. L. Biró, who collected the type series and specimens of several other species on which the current revision of Baeturia is based.

Baeturia inconstans n. sp.

(Figs. 1, 33-40)

Material examined. - Types: Holotype: "Finschhafen / New Guinea / iv.15.44/E.S. Ross" [print]; "Collection of the / CALIFORNIA ACADEMY / OF SCIENCES, San / Francisco, Calif." [Print], $\uparrow$, CAS. Paratypes: same data as holotype but iv-v.1944, 6 ơ ơ, 5 \& \&, CAS; same data $2 \sigma^{\circ} \sigma^{\circ}, 1$ \%, ZMA.

Other material: IRIAN JAYA: New Guinea (W.): Hollandia,

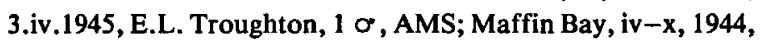
E.S. Ross, 1 १, CAS; Oransbari N., Geelvink Bay, $\pm 3 \mathrm{~m}$, 15.ii.1963, R. Straatman, 1 \&, BPBM.

PAPUA: New Guinea (N.E.): Brahman Miss. Madang Prov., J. van Stalle, 1 \& , KBIN; Bulolo river, 680 m, 4.vi.1969, J. Sedlacek, 1 ९, BPBM; same data but 23.iv.1969, 1 \%; 30.v.1969, 1 \% , both BPBM; Bulolo, 700 m, 18.vi.1969, J. Sedlacek, $1 \propto$, BPBM; same data but 6.xi.1969, 1 \&, BPBM; same data but 6.i.1970, 1 ơ, ZMA; Bulolo 11.2 km N., 600 m, ii-iii.1966, J. Sedlacek, 1 ơ, BPBM; Bulolo, Vatut, 800 m, 1-7.vi.1969, J. Sedlacek, $1 \sigma$, BPBM; Bupu River, Situm vill. 19 km N.E. of Lae, 15.iv-15.v.1970, N.R. Spencer, 1 \% , BPBM; Busu River, E. of Lae, $100 \mathrm{~m}, 13 . i x .1955$, J.L. Gressitt, $1 \sigma^{\circ}$, BPBM; Finschhafen, iv.1944, F.E. Skinner, 1 \% , BPBM; Gingala, Huon Gulf, 24.x.1898, Biró, 1 \%, TMB; Lae, 30 m, 2.iv.1962, J. Sedlacek, $1 \%, 1$, BPBM; same data but 1-2.v.1962, 1 o, BPBM; Lae, Bumayeng, 4-8.ix.1965, H. Pyka, $1 \sigma$, SMN; Lae, Küste, 14.iv.1965, H. Pyka, 1 \&, SMN; Sattelberg, Huon Gulf, 1898, Biró, 1 ९, TMB; same data but 22.ix.1898, 1 \%; 28.xi.1898, 1 ơ, both TMB; Simbang, Huon Gulf, 27.ii.1899, Biró, 1 \&, TMB; Tamara, Berlinhafen, 8.ix.1896, Biró, 2 ơ ơ, TMB; same data but 10.ix.1896, $1 \sigma^{\circ}$, TMB; same data, $1 \sigma^{\circ}, \mathrm{ZMA}$; Ulap, Wasu, 1200 m, 1-8.viii.1965, H. Pyka, 1 o , 1 \%, SMN; Wau, v.1969, J. Sedlacek, 1 \&, ZMA; Wau, 1100-1300 m, 2.i.1966, L. \& M. Gressitt, 1 \&, BPBM; Wau, 1150-1250 m, 12.i.1966, J. Sedlacek, 1 \% , BPBM; same data but 25.i.1966, 1 \%; $1200 \mathrm{~m}, 8$. ii.1966, $1 \sigma^{\circ}$, both BPBM; Wau, $1200 \mathrm{~m}$, 12-23.v.1965, H. Pyka, 1 ơ, SMN; Wau, Bulolo river, 850-950 m, 4.ii.1966, J. Sedlacek, 1 \&, BPBM; Wau, Coivak ridge, $763 \mathrm{~m}$, 7.xii.1963, H. Clissold, 1 o , 1 \&, ZMA; Wau, Mt. Missim, 950-1300 m, 8-9.i.1966, J. \& M. Sedlacek, 1 \%, BPBM; Wau, Morobe district, 1050 m, 5.i.1961, G. Monteith, 1 ९, BPBM; same data but 18.xii.1961, J. \& J.H. Sedlacek, 1 ९, BPBM; Wau, Morobe district, $1100 \mathrm{~m}, 31 . i .1963$, J. Sedlacek, 1 \% , BPBM; same data but $1150 \mathrm{~m}, 2 . x .1961,1 \% ; 1200$ m, J. \& M. Sedlacek, 1 \&, both BPBM; Yagaum, Madang, 70 m, 20.vi.1965, H. Pyka, 5 ơ ơ, 1 \&, SMN; Zenag, Lae, 200 m, 15.i.1965, J. Sedlacek, 2 \% , BPBM.

Note. - Three females, with the following data: Wau area Morobe P. iii.iv.1984, T.R. New, 1 \&, Moul; Wau, Wau Ecology Inst., 1220 m, 18-20.vi.1981, J. van Goethem, 1 \&, KBIN; Wau W.E.I., 25.v.1982, P. Grootaert, 1 \&, KBIN, share a similarly variable tegmen venation with $B$. inconstans, but are distinctly larger (body length: 19.7-21.3 mm). These specimens might belong to a different, but related, species.

Remarks. - The phylogenetic position of this species is somewhat uncertain. Males have a strongly concave distal margin of the pygofer, sharply edged protuberances on the lateral lobes of the pygofer, and often a prominent crest across the base of the clasper. These features are characteristic of species of the viridis group (De Boer, 1992a). The shape of the apical part of the clasper, and of the male caudodorsal beak places this species in the guttulinervis group.

This species is most easily recognized by the number of apical areas in the tegmen, varying between 10 and 14, and often differing between the right and left tegmen of individuals. Similarly variable tegmen venation occurs in four species of the genus Gymnotympana Stål and nearly all species of the genus Thaumastopsaltria Kirkaldy, but is unknown for other Baeturia species (see note above).

Description. - Body of males pale ochraceous, more or less densely brown speckled. Females generally darker, more reddish brown. Females of about the same size as males, but with longer tegmina. Male abdomen 1.3-1.5 times as long as head and thorax, of females 1.0-1.1 times as long. 
Tegmina of males 1.1-1.3 times as long as body length, of females 1.3-1.5 times as long. Some specimens have a light and immaculate middorsal band on head and thorax, while in others this band is darkened by a concentration of the speckling.

Head: Light ochraceous, generally brown speckled all over, but sometimes only speckled on vertex lobes and lateral parts of postclypeus, or almost unspeckled. Postclypeus angularly protruding, 1.62.3 times as broad as long, and not swollen, anterior margin (lateral view) slightly convex, almost straight.

Thorax: Pronotum light brown, slightly brown speckled or unspeckled, in some specimens with a lighter and immaculate medial band, while in others the brown speckling concentrates in this band. Mesonotum greyish brown, generally brown speckled, though sometimes cruciform elevation and triangular area in front of elevation unspeckled. Most specimens with pair of dark spots in front of elevation.

Tegmina and wings: Hyaline. Tegmina with variable venation; the number of apical areas varies between 10 and 14, and often differs between left and right tegmen of individuals. Wings with six apical areas. Veins ochraceous and densely set with short setae. Tegmina with distinct costal area.

Tymbal: Fairly small, as in the foregoing species. Four transverse sclerotized ridges spanning the tymbal from dorsal to ventral margin and a fifth ridge, hardly separated from the proximal tymbal margin, almost reaching ventral margin. Four short intercalary ridges form a band across tymbal. Dorsal part of tymbal tinged with red.

Opercula: Male operculum (Fig. 36) very small, only covering a small part of tymbal cavity in ventral view. Distal part of male operculum ovalshaped and almost erect. Lateral margin almost straight and strongly directed mesiad, making an obtuse angle with the rectangular crest around distolateral corner of basal part. Distomedial corner strongly convex, almost angular. Operculum extending medially just beyond medial margin of meracanthus. Apex of meracanthus reaching well beyond operculum. Female operculum (Fig. 40) sickle-shaped and erect. Basal part of female operculum much larger than in male.
Abdomen: Male abdomen light brown, and almost transparent, in most specimens unspeckled, in others slightly brown speckled in dorsal band and on 8th segment. Segmental hind margins red. Some specimens with very distinct ventrolateral row of dark spots on abdominal segments 3-8, others have one pair of spots on segment 3 and sometimes on segment 8 only. Female abdomen castaneous brown and slightly speckled. Ventrolateral spots vaguely visible. Female caudodorsal beak (Fig. 37) long, slender, and apically pointed.

Male genitalia: Pygofer in lateral view (Fig. 33) strongly rounded as in foregoing species. Dorsal margin strongly convex, continuous with rounding of caudodorsal beak, and not concave near apex of beak. Distal margin of pygofer strongly concave, almost semicircular, continuously rounded from margin of caudodorsal beak to apex of protuberance on lateral lobe of pygofer, as in species of the viridis group (De Boer, 1992a). Ventral margin almost straight, angularly bent just under lateral protuberance; ventral margins converge to a sharp angle at base of pygofer opening. Caudodorsal beak in dorsal view (Fig. 34) rounded at apex. Lateral lobes of pygofer with well-developed, distinctly posteriorly projecting and apically pointed, protuberances. These protuberances not rounded as in foregoing species, but flattened and with a sharp lateral edge, as in species of the viridis group. Clasper in lateral view (Fig. 35) very short and straight, resembling that of $B$. roonensis, but with straight dorsal margin, with strongly inflated apical part and a distinct crest around the small clasper hollow. Crest along dorsal margin broader, often more rounded, than in $B$. roonensis, however. Clasper base in most specimens with distinct and angular clasper heel. Some specimens with very distinct and prominent crest across clasper base, as described for some species of the viridis group (De Boer, 1992a), in others this crest lies farther back into the pygofer. Aedeagus in lateral view (Fig. 38) closely resembling that of $\boldsymbol{B}$. biroi, but with shorter and broader lateral lobes. Aedeagus from behind (Fig. 39) almost straight between lateral lobes, and without crest between these lobes. Aedeagal pore narrow and oval. 


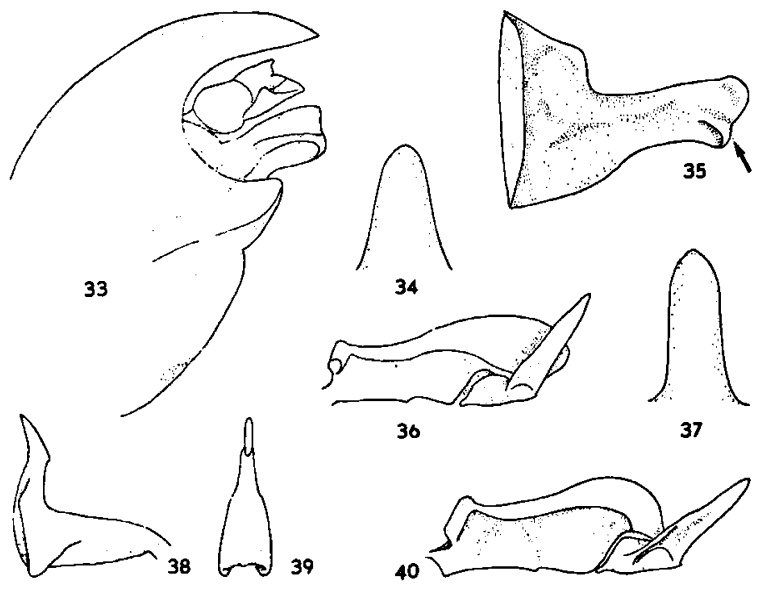

Figs. 33-40. Baeturia inconstans n. sp.: 33, male pygofer in lateral view, holotype; 34 , male caudodorsal beak in dorsal view, holotype; 35 , clasper, Bulolo, arrow indicating crest around clasper hollow; 36 , male operculum, holotype; 37 , female caudodorsal beak in dorsal view, Finschhafen; 38, aedeagus in lateral view, Bulolo; 39, aedeagus from behind, Bulolo; 40, female operculum, Finschhafen.

Measurements. - Body length $\sigma$ : 14.1-17.5 mm (mean 16.1 $\mathrm{mm} \pm 0.8$ ), $\%: 14.1-17.8 \mathrm{~mm}$ (mean $16.0 \mathrm{~mm} \pm 0.9$ ); tegmen length o': 16.4-20.8 mm (mean $18.6 \mathrm{~mm} \pm 1.1)$, $\$: 19.8-22.5$ $\mathrm{mm}$ (mean $21.0 \mathrm{~mm} \pm 0.9$ ); head length $\sigma^{\prime}: 1.3-1.8 \mathrm{~mm}$ (mean $1.6 \mathrm{~mm}$ ), $:$ : $1.4-1.8 \mathrm{~mm}$ (mean $1.7 \mathrm{~mm}$ ); pronotum length $\sigma^{\circ}$ : 2.1-2.6 mm (mean $2.3 \mathrm{~mm}$ ), $\$: 2.2-2.8 \mathrm{~mm}$ (mean $2.5 \mathrm{~mm}$ ); mesonotum length $\sigma^{\prime}: 3.5-4.4 \mathrm{~mm}$ (mean $3.9 \mathrm{~mm}$ ), $\mathrm{mm}$ (mean $4.1 \mathrm{~mm}$ ); head width or: $3.5-4.4 \mathrm{~mm}$ (mean 4.0 $\mathrm{mm}$ ), : : 3.9-4.6 mm (mean $4.2 \mathrm{~mm}$ ); width of pronotal collar o : 4.8-5.6 mm (mean $5.2 \mathrm{~mm}$ ), $९: 5.3-6.3 \mathrm{~mm}$ (mean 5.7 $\mathrm{mm})$.

Distribution (Fig. 1). - B. inconstans is distributed along the northern parts of New Guinea, but most of the available material comes from around Huon Gulf, the Huon peninsula, and the northern parts of the Papuan peninsula.

Etymology. - The name inconstans refers to the variable tegmen venation of this species.

\section{Acknowledgments}

For the loan of material I am indebted to: Mr. B.J. Day and Mr. M.S. Moulds (AMS); Mr. G.M. Nishida and Mr. K. Arakaki (BPBM); Dr. P.H. Arnaud (CAS); Mr. J. van Stalle (KBIN); Mr. J. van Tol (RMNH); Dr. T. Vásárhelyi (TMB); Dr. H.
Strümpel (ZIM); and to Dr. U. Göllner-Scheiding and Dr. J. Deckert (ZMB).

I would like to thank Mr. G. Verlaan for technical assistance and Mr. D.A. Langerak for preparing the map (Fig. 1). I am indebted to Prof. Dr. F.R. Schram and Dr. J.P. Duffels (Institute of Systematics and Population Biology, Amsterdam) for their critical reading and comments on the manuscript.

\section{References}

Anonymous, 1938. Atlas van tropisch Nederland: [i-ix], maps 1-31b, legenda 1-31b, 1-17 (Koninklijk Nederlands Aardrijkskundig Genootschap \& Topografische Dienst in Nederlandsch-Indië, Amsterdam/Batavia).

Anonymous, 1966. List of New Guinea localities: 1-19 (Bernice P. Bishop Museum, Honolulu).

Anonymous, 1968. The Times atlas of the world: i-xliii, 1-272, pls. 1-123 (Times Newspapers Ltd., London).

Blöte, H.C., 1960. The genus Baeturia Stäl as represented in New Guinea (Homoptera, Cicadidae). Zoöl. Meded., Leiden, 37: 61-80.

Boer, A.J. de, 1982. The taxonomy and biogeography of the nasuta group of the genus Baeturia Stål, 1866 (Homoptera, Tibicinidae). Beaufortia, 32(4): 57-78.

Boer, A.J. de, 1986. The taxonomy and biogeography of the conviva group of the genus Baeturia Stả, 1866 (Homoptera, Tibicinidae). Beaufortia, 36(7): 167-182.

Boer, A.J. de, 1989. The taxonomy and biogeography of the bloetei group of the genus Baeturia Stàl, 1866 (Homoptera, Tibicinidae). Beaufortia, 39(1): 1-43.

Boer, A.J. de, 1990. Aedeastria, a new cicada genus from New Guinea, its phylogeny and biogeography (Homoptera, Tibicinidae), preceded by a discussion on the taxonomy of New Guinean Tibicinidae. Beaufortia, 40(3): 63-72.

Boer, A.J. de, 1992a. The taxonomy and biogeography of the viridis group of the genus Baeturia Stål, 1866 (Homoptera, Tibicinidae). Bijdr. Dierk., 61(3): 163-183.

Boer, A.J. de, 1992b. The taxonomy and biogeography of the genus Thaumastopsaltria Kirkaldy, 1900, (Homoptera, Tibicinidae). Beaufortia, 43(3): 17-44.

Boer, A.J. de, 1993a. Ten new species of the genus Aedeastria De Boer, 1990, with notes on the taxonomy and biogeography (Homoptera, Tibicinidae). Beaufortia, 43(9): 140-167.

Boer, A.J. de, 1993b. Guineapsaltria, a new genus of the Australian - New Guinean region (Homoptera, Tibicinidae), with notes on its taxonomy and biogeography. Bijdr. Dierk., 63(1): 15-41.

Boer, A.J. de, in press a. The taxonomy and biogeography of the loriae group of the genus Baeturia Stål, 1866 (Homoptera, Tibicinidae). Tijdschr. Ent., 137.

Boer, A.J. de, in press b. The taxonomy and biogeography of the exhausta group of the genus Baeturia Stål, 1866 (Homoptera, Tibicinidae). Beaufortia, 44.

Daly, M.C., M.A. Cooper, I. Wilson, D.G. Smith \& B.G.D. 
Hooper, 1991. Cenozoic plate tectonics and basin evolution in Indonesia. Marine and Petroleum Geology (MPGD), 8(1): $1-21$.

Duffels, J.P., 1986. Biogeography of Indopacific Cicadoidea, a tentative recognition of areas of endemism. Cladistics, 2(4): 318-336.

Duffels, J.P. \& A.J. de Boer, 1990. Areas of endemism and composite areas in East Malesia. In: P. Baas, C. Kalkman \& R. Geesink (eds.), The plant diversity of East Malesia: Proceedings of the Flora Malesiana Symposium commemorating Professor Dr. C.G.G.J. van Steenis, Leiden, August 1989: 249-272 (Kluwer Academic Publishers, Dordrecht).

Duffels, J.P. \& P.A. van der Laan, 1985. Catalogue of the Cicadoidea (Homoptera, Auchenorhyncha) 1956-1980. Series Ent., 33: i-xvi, 1-414.

Hamilton, W.B., 1979. Tectonics of the Indonesian region. U.S. Geol. Surv. prof. Pap., 1078: i-ix, 1-345.

Pigram, C.J. \& H.L. Davies, 1987. Terranes and the accretion history of the New Guinea orogen. B.M.R. J. Aust. Geo. Geoph., 10: 193-212.

Pigram, C.J. \& H. Panggabean, 1984. Rifting of the northern margin of the Australian continent and the origin of some microcontinents in eastern Indonesia. Tectonophysics, 107: 331-353.

Rangin, G., L. Jolivet \& M. Pubellier, 1990a. A simple model for the tectonic evolution of the southeast Asia and Indonesia region for the past $43 \mathrm{~m}$. y. Bull. Soc. géol. Fr., (8) 6 (6): 889-905.

Rangin, G., M. Pubellier, J. Azema, A. Briais, P. Chotin, H. Fontaine, P. Huchon, L. Jolivet, R. Maury, C. Muller, J.-P. Rampnoux, J.-F. Stephan, J. Tournon, N. Cottereau, J. Dercourt \& L.E. Ricou, 1990b. The quest for Tethys in the western Pacific. 8 paleogeodynamic maps for Cenozoic time. Bull. Soc. géol. Fr., (8) 6 (6): 907-913.

Received: 7 September 1993 